\section{From Discovery to Use \\ Traversing the World of Commercializing Biocontrol Agents for Plant Disease Control}

\author{
D. E. Mathre \\ Montana State University, \\ Bozeman
}

\section{R. J. Cook}

Washington State University, Pullman

\section{N. W. Callan}

Western Agricultural Research Center, Montana State University, Bozeman
Microorganisms play an enormously important role in plant disease control. As naturally occurring resident antagonists, they can be managed or exploited to achieve the desired results. They are responsible for the "crop rotation effect," which is possibly still the single most important disease management tool used worldwide. Simply not growing the same crop in the same field more than every second or third year allows time for the resident antagonists to lower the inoculum potential of root- and many foliar-infecting pathogens of that crop below some economic threshold before that crop is again grown in that field. With the possible exception of hyperparasites of sclerotia $(1,50,55)$, plant pathologists have never seriously thought it would be possible to shorten or eliminate the time required for crop rotation by adding specific strains of microorganisms-introduced antagoniststo soil. On the other hand, the addition of organic materials such as compost, barnyard manure, and green manure is known to intensify the soil-sanitizing benefits of resident antagonists so much that it is sometimes possible to eliminate the need for crop rotation. In fact, this practice, and the experimental demonstration of its stimulatory effects on resident antagonists, is credited with having launched biological control as an area of research in plant pathology during the early part of this century (4).

Entomology is commonly used as the standard for success with biological control agents introduced into the environment. Compared case-for-case, plant pathology is a barely-visible distant second to entomology. In fact, we would have to say it is a

Dr. Mathre's address is: Department of Plant Sciences, 208 Ag Biosciences, Montana State University, Bozeman

E-mail: upldm@montana.edu

Publication no. D-1999-0823-03F

(C) 1999 The American Phytopathological Society distant third, since there are more successful cases with introduced biological control agents of weeds-herbivorous insects and pathogens - than of plant diseases. On the other hand, if we narrow the comparison to biological control with introduced microorganisms, plant pathology begins to look quite respectable. Other than Bacillus thuringiensis $(\mathrm{Bt})$, there are more microbial biocontrol agents registered with the U.S. Environmental Protection Agency (EPA) for use against plant pathogens than against either arthropod pests or weeds (14). There are no living microorganisms registered with the EPA for biological control of plant parasitic nematodes.

Biological control with introduced microorganisms presents challenges not encountered with parasitic or predatory insects used as natural enemies of arthropod pests or weeds, especially when that microorganism does not depend on the target pest as a host, which is the case with the vast majority of antagonists of plant pathogens. Plant pathology must deal with the additional challenge that the target "pest" is, itself, a microorganism. Many of the principles of biological control developed for the use of parasites, predators, and pathogens of arthropod pests and weeds are not relevant for antagonists of plant pathogens (13). In fact, the principles and approaches developed for biological control of animal and human diseases-vaccination and probiotics - are just as relevant to plant pathology as the principles and approaches developed for biological control of arthropod pests and weeds with natural enemies. One rather daunting principle that applies across all biological methods for disease and pest control with introduced agents (including genes for disease resistance) is that, with few exceptions, a different agent (or gene) is needed for each disease or pest and each crop species or related crop species. A root-associated microorganism with broad-spectrum antibiotic activity might suppress more than one disease but often exhibits other speci- ficities such as host preference or adaptation to certain soil types.

Research on biological control of plant pathogens received major impetus and attracted many young investigators because of the 1963 international symposium held at the University of California, Berkeley, and published under the title "Ecology of Soilborne Plant Pathogens-Prelude to Biological Control" (5). Interestingly, only one example of biological control with an introduced antagonist was even mentioned at this 5-day symposium. This was Rishbeth's (43) biological control of annosus root rot of pine with Phlebia gigantea applied to freshly cut stumps to preempt colonization of the stumps by the pathogen Heterobasidion annosum. Rishbeth's approach, followed during the early 1970s by Kerr's development of Agrobacterium radiobacter $\mathrm{K} 84$ for biological control of crown gall (25), changed the direction of thinking on use of introduced antagonists in at least two ways: (i) antagonists, like the pathogen, should be adapted to the host plant to be protected, in addition to their ability to inhibit or compete with the target pathogen; and (ii) antagonists that can be applied directly and precisely to the infection court need not be able to spread or even persist in the environment. These two examples of biological control sparked the current and much more successful effort with plant-associated microorganisms as agents introduced for biological control of plant pathogens.

\section{Commercialization Efforts to Date}

The efforts under way today to commercialize a biological control agent for use against a plant disease can be grouped for purposes of discussion into three categories based on both increasing level of difficulty and decreasing potential for repeat sales. These categories are not black and white, but they help indicate the direction for developing biocontrol agents as well as the bases for commercial successes to date. 
The first group, which follows the lead of Rishbeth and Kerr, is to apply the antagonist directly and precisely to the infection court when and where needed. This group also exemplifies the strategy based on an inundative application, where the antagonist is applied at an instantly high and timely population with the intent to preempt or swamp the pathogen (14). This includes examples of seed-applied antagonists for protection of germinating seeds against damping-off. It also includes examples of antagonists applied to fruits for protection against fruit decay in storage, and ice-minus bacteria commercialized for protection of plants against frost injury (29). Nearly all microorganisms commercialized for biological control of plant diseases fall into this first group. One exception, Gliocladium virens GL-21 (30), is applied to soil but in close enough proximity to the seed or plant or at inoculum densities necessary to assure an instantly high population in the infection court when and where needed. Some of the agents commercialized for use against damping-off also have the ability to colonize the rhizosphere, e.g., Trichoderma harzianum (20), but their use is still limited mostly to improving stand establishment and seedling vigor, and they compete in the marketplace with the seed treatment chemicals developed for this same use. This group of antagonists represents the logical first step in commercialization of microbial biocontrol agents for use against plant diseases, and it contributes significantly to experience and familiarity with microbial biocontrol within the industry, among growers, and within society more generally.

The second group includes antagonists applied at one place, e.g., on seeds, with the intent that they will spread and protect the plant at one or more distant places, e.g., the shoots or roots. Plant growth promoting rhizobacteria (PGPR) fall into this category (28). In the case of fluorescent pseudomonads under development for biological control of wheat take-all, protection is needed exclusively on seminal and crown roots and subcrown internodes, since the pathogen does not infect the seeds (53). This group of antagonists can include cases that exemplify the strategy of inundative application, but more likely, their use exemplifies the strategy of augmentative application, where the antagonist is expected to multiply, persist for part or all of the life of the plant, and augment a background but inadequate population of a related or similar antagonist (14). An example is the use in Arizona of an atoxigenic Aspergillus flavus to spread from colonized wheat grains scattered on the soil surface onto the floral parts of cotton plants, where they preempt establishment of toxigenic strains of A. flavus (18). Through a cooperative effort involving USDA-ARS, cotton growers in Arizona, and the Interregional Research Project 4
(IR-4), plans are under way with a request for approval by the EPA (Federal Register 64:28371-28374) to treat 20,000 acres of cotton in 1999 with the atoxigenic isolate AF36 of A. flavus as a biocontrol of the toxigenic strains of this taxon. Another example is the use of Sporidesmium sclerotivorum added to soil to reduce the population of sclerotia of Sclerotinia minor (1). This category of examples obviously represents a much more challenging approach to biological control because of the greater vulnerability of the introduced agent to the effects of competition and environmental conditions. No antagonist that fits neatly into this group has been commercialized. On the other hand, this group continues to attract attention because these agents, like the first group, represent the potential for repeat sales, and because the competing commercial products, if they exist, are soil fumigants or foliarapplied chemicals but not seed treatments.

The third category of antagonists includes cases that would exemplify the strategy of effective biological control following a one-time or occasional inoculative release (14). Most of the successful examples of biological control of perennial weeds and insects with microorganisms (other than Bt) are of this type, because the microbial biocontrol agents are pathogens dependent for their ability to multiply and persist on the target pest, their host, and because the perennial nature of the target pest gives them time to become effective. Certain hyperparasites of the reproductive structures of pathogens of perennial plants could fit into this category, e.g., the unsuccessful attempts to use Tuberculina maxima as a hyperparasite of the aecial stage of the white pine blister rust fungus in the Pacific Northwest (4). While it is too early in the research, it will be interesting to determine whether the atoxigenic strain of A. flavus that is showing such potential for biological control of toxigenic strains might become established over time and therefore fit somewhat into this category of biological control. Aside from these kinds of examples, our third category is more hypothetical than actual as an approach to commercial products for biological control of a plant pathogen, nor would there be potential for repeat sales. Development of this category of biological control, where it can be effective, will obviously depend on public-sector research since it will not likely attract private-sector investment, other than possibly from grower and commodity groups and cooperatives.

Considering the worldwide efforts in public-sector research and development on biological control with introduced antagonists since the accomplishments of Rishbeth in the early 1960s and Kerr in the early 1970s, and even allowing for the challenges outlined above, it can fairly be asked why more commercial products have not been developed. To address this ques- tion, we provide brief reviews of three projects carried out in our respective programs, each with the intent to produce a commercial product, and each not yet at the stage of commercialization. Finally, we provide some take-home messages based on our experiences.

\section{Pseudomonas aureofaciens AB254 and Pythium Seed Rot}

Many vegetable crops are affected by preemergence seed rot or damping-off caused by Pythium spp., particularly $P$. ultimum in cool climates. Stand establishment of sweet corn carrying the sh2 gene for elevated sugar content may be especially difficult to achieve when soils are cold and wet at planting (Fig. 1). Cucurbitaceous crops such as cucumbers, melons, and squash likewise are notoriously susceptible to Pythium seed rot. In addition, germination of seeds of sweet corn and certain other warm-season crops is reduced by imbibitional chilling injury, in which cell membrane damage occurs when seeds imbibe water at low temperatures. Presowing seed hydration or "priming" treatments were designed to resolve this and other physiological problems. We wished to develop a biological seed treatment that would both protect the seed from Pythium seed rot and alleviate physiological stress, a treatment hereafter referred to as biopriming.

The bacterial biocontrol agent Pseudomonas aureofaciens AB254 (P. fluorescens biovar V) was isolated in $1988(7,32)$. Soils were sampled from 10 locations in the Bitterroot Valley in western Montana. Sweet corn seeds were sown in each soil, and germinated seeds were incubated with mycelial mats of $P$. ultimum in phosphate buffer. The mycelial mats were rinsed repeatedly, and bacteria were isolated from later rinses. Biocontrol screening was done by testing for: (i) a zone of inhibition of $P$. ultimum on potato dextrose agar, (ii) inhibition or death of a $P$. ultimum mycelial mat after incubation with the bacterial isolate in cornmeal broth, (iii) protection of sh2 sweet corn seed by bacterial seed coating in greenhouse trials with naturally P. ultimum-infested soil, and (iv) field testing at the Western Agricultural Re-

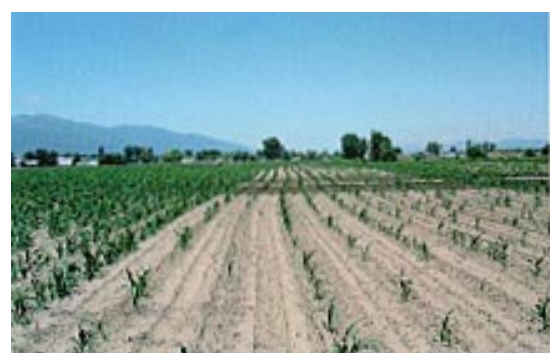

Fig. 1. Sweet corn field in western Montana exhibiting severe stand problems as a result of Pythium seed rot caused by Pythium ultimum. 
search Center, Corvallis, Montana, (WARC) and other locations.

For bio-priming, seed is coated with a suspension of $\mathrm{AB} 254$ and then incubated under warm, moist conditions until just prior to radicle emergence. The seeds may be planted immediately or dried for storage.
During the years 1989 to 1998 , over 40 field tests involving $\mathrm{AB} 254$ treatments of sh2 sweet corn were conducted in locations in Montana, Idaho, Minnesota, Ohio, and New York. Seed protection was consistently achieved with AB254, and stands equal to or better than those with metalaxyl treatment

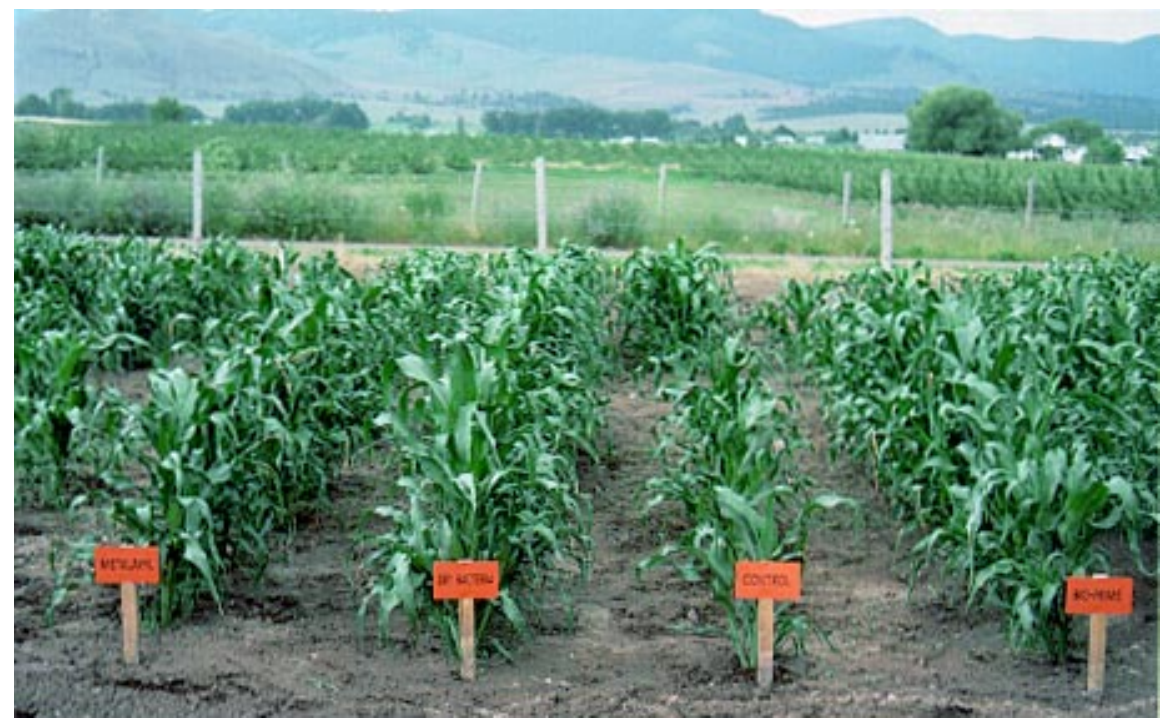

Fig. 2. Effect of seed treatment on control of Pythium seed rot in sh2 sweet corn. Left to right: metalaxyl treated, Pseudomonas AB 254 applied to seed and allowed to dry prior to seeding, control - no seed treatment, and bio-primed with Pseudomonas AB 254. Note differences in stand and plant vigor between the control and the three treatments.

Table 1. Seedling emergence (\%) of sh2 sweet corn after the bio-priming seed treatment with Pseudomonas aureofaciens $\mathrm{AB} 254^{\mathrm{x}}$

\begin{tabular}{lccccc}
\hline & \multicolumn{5}{c}{ Seed treatment } \\
\cline { 2 - 6 } Location & Untreated & $\begin{array}{c}\text { Bio-primed, } \\
\text { planted moist }\end{array}$ & $\begin{array}{c}\text { Bio-primed, } \\
\text { planted air-dry }\end{array}$ & $\begin{array}{c}\text { Coated with } \\
\text { AB254 }\end{array}$ & Metalaxyl \\
\hline Corvallis, MT ${ }^{\mathrm{y}}$ & $50 \mathrm{a}^{\mathrm{z}}$ & $68 \mathrm{~b}$ & $70 \mathrm{~b}$ & $66 \mathrm{~b}$ & $69 \mathrm{~b}$ \\
Corvallis, MT $^{\mathrm{y}}$ & $48 \mathrm{a}$ & $71 \mathrm{~b}$ & $79 \mathrm{~b}$ & $70 \mathrm{~b}$ & $70 \mathrm{~b}$ \\
Waseca, MN $^{\mathrm{y}}$ & $65 \mathrm{a}$ & $83 \mathrm{~b}$ & $87 \mathrm{~b}$ & $79 \mathrm{~b}$ & $78 \mathrm{~b}$ \\
Nampa, ID & $29 \mathrm{a}$ & $62 \mathrm{~b}$ & $49 \mathrm{~b}$ & $54 \mathrm{~b}$ & $60 \mathrm{~b}$ \\
Creston, MT & $81 \mathrm{a}$ & $91 \mathrm{~b}$ & $87 \mathrm{ab}$ & $86 \mathrm{ab}$ & $87 \mathrm{ab}$ \\
Huson, MT & $61 \mathrm{a}$ & $66 \mathrm{a}$ & $71 \mathrm{a}$ & $70 \mathrm{a}$ & $66 \mathrm{a}$ \\
Mean & $56 \mathrm{a}$ & $74 \mathrm{~b}$ & $74 \mathrm{~b}$ & $71 \mathrm{~b}$ & $72 \mathrm{~b}$ \\
\hline
\end{tabular}

x Cultivar: Crisp 'n Sweet 710 (Crookham Co., Caldwell, ID) except Nampa, ID, which was Supersweet Jubilee (Rogers Seed Co., Nampa).

y Data from Mathre et al. (31).

${ }^{\mathrm{z}}$ Mean separation within rows by protected LSD, $P<0.05$. were obtained in $88 \%$ of the plantings in which Pythium seed rot occurred (Fig. 2).

We felt the bio-priming process had potential advantages over simply coating seed with AB254. Seed priming often results in more rapid and uniform seedling emergence and may be useful under adverse soil conditions such as low temperature or excess soil moisture. Sweet corn seedling emergence in Pythium-infested soil was increased by $\mathrm{AB} 254$ at a range of soil temperatures, but emergence at $10^{\circ} \mathrm{C}$ was slightly higher from bio-primed seeds than from seeds coated with the bacterium (31). The greatest advantage of bio-priming over coating was seen when seeds were planted in excessively wet soil infested with $P$. ultimum. Emergence from bio-primed seed was $38 \%$ at a water potential of $-0.01 \mathrm{MPa}$ compared with only $5 \%$ for seed coated with AB254 and no emergence from untreated seed (31). In addition, bio-priming could reduce the amount of bacterial inoculum that must be applied to seed. A minimum of $10^{7} \mathrm{CFU}$ per seed was needed for protection of $s h 2$ sweet corn seed from Pythium seed rot, but the rapid rate of multiplication of AB254 on seed during bio-priming enabled an initial population of $10^{4}$ to $10^{5} \mathrm{CFU}$ per seed to increase to $10^{7} \mathrm{CFU}$ per seed during priming (8). This strategy would only be practical if the advantages conferred by the treatment justified the additional expense of priming and drying the seed.

Six field tests were conducted in 1990 to compare seedling emergence from seed coated with a suspension of AB254 to that from seed that had been bio-primed. Pythium seed rot was evident in four tests, as indicated by the effectiveness of the fungicide metalaxyl (Table 1). Seed protection comparable to metalaxyl treatment was achieved whether seed was coated or bioprimed with $\mathrm{AB} 254$. Bio-priming did not provide additional protection from $\mathrm{Py}-$ thium seed rot over coating with AB254 in these field tests, but did improve seedling emergence of three sweet corn cultivars in tests conducted in 1997 (Table 2). Biopriming may be advantageous in cold or waterlogged soil where priming would provide a physiological benefit to the seed.

Table 2. Seedling emergence (\%) of sweet corn cultivars after seed treatment with Pseudomonas aureofaciens AB254v

\begin{tabular}{|c|c|c|c|c|c|c|c|}
\hline \multirow[b]{2}{*}{ Seed treatment } & \multicolumn{7}{|c|}{ Sweet corn cultivar } \\
\hline & $\begin{array}{c}\text { Supersweet } \\
\text { Jubilee }(\operatorname{sh} 2)\end{array}$ & $\begin{array}{c}\text { Crisp 'n Sweet } \\
710(s h 2)\end{array}$ & $\begin{array}{l}\text { Northern Extra- } \\
\text { sweet }(\operatorname{sh} 2)\end{array}$ & $\begin{array}{c}\text { How Sweet it } \\
\text { Is (sh2) }\end{array}$ & $\begin{array}{l}\text { Honey and } \\
\text { Pearl (sh2) }\end{array}$ & $\begin{array}{l}\text { Bodacious } \\
\quad(s e)\end{array}$ & $\begin{array}{c}\text { Jubilee } \\
\text { (se })\end{array}$ \\
\hline Metalaxyl $^{\mathrm{w}}$ & $84 a^{x}$ & $80 \mathrm{~b}$ & $90 \mathrm{a}$ & $69 \mathrm{ab}$ & $74 \mathrm{a}$ & $96 \mathrm{a}$ & $97 \mathrm{a}$ \\
\hline AB254 bio-prime ${ }^{y}$ & $79 \mathrm{a}$ & $91 \mathrm{a}$ & $81 \mathrm{~b}$ & $71 \mathrm{a}$ & $71 \mathrm{a}$ & $87 \mathrm{~b}$ & $97 \mathrm{a}$ \\
\hline $\mathrm{AB} 254^{\mathrm{z}}$ & $77 \mathrm{a}$ & $81 \mathrm{~b}$ & $90 \mathrm{a}$ & $63 \mathrm{~b}$ & $71 \mathrm{a}$ & $75 \mathrm{c}$ & $93 \mathrm{a}$ \\
\hline Untreated & $62 \mathrm{~b}$ & $73 \mathrm{~b}$ & $52 \mathrm{c}$ & $26 \mathrm{c}$ & $38 \mathrm{~b}$ & $36 \mathrm{~d}$ & $85 \mathrm{~b}$ \\
\hline
\end{tabular}

v Planted at Western Agricultural Research Center on 9 May 1997.

${ }^{\mathrm{w}}$ Applied at $0.3 \mathrm{~g}$ a.i. $/ \mathrm{kg}$.

${ }^{x}$ Mean separation within columns by protected LSD $(P<0.05)$ with 6 replicates.

${ }^{\mathrm{y}}$ Hydration of seed coated with a methylcellulose (MC) suspension of AB254 for $20 \mathrm{~h}$ prior to planting, seed not dried before planting.

${ }^{\mathrm{z}}$ Coated with a suspension of AB254 in carboxymethylcellulose (CMC) and $0.25 \mathrm{M}$ sucrose, air-dried before planting. 
Once the value of AB254 had been described, Montana State University wanted to see it commercialized. To this end, a request was made for interested companies to submit proposals to the MSU Research and Development Institute. Bozeman Biotech, Inc., of Bozeman, Montana, was selected to develop AB254 into a commercial product. Bozeman Biotech was awarded a USDA-SBIR Phase I grant and eventually a Phase II grant to fund this work.

Before commercialization of AB254 would be initiated, several factors needed to be considered. In addition to assessing the range of crops for which this technology might be applicable, answers were needed on how the bacterial inoculum might be formulated and economically produced, how the viability or shelf life of the treated seed might be extended, and how AB254 might be applied to seed using commercial-scale equipment. These factors were investigated over a 2-year period in a subcontract between Bozeman Biotech and Montana State University.

The ability of AB254 to protect germinating seeds of different species and cultivars of vegetable crops was of interest for commercialization of this strain. Seed of sweet corn, peas, and squash were treated by a simulated commercial seed treatment at Bozeman Biotech or, for sweet corn, bio-primed in the laboratory at WARC. Seeds of both $s h 2$ and se sweet corn were protected from Pythium seed rot, most at a level equivalent to treatment with the fungicide metalaxyl (Table 2). Seedling emergence of pea and squash cultivars was also improved by $\mathrm{AB} 254$, in most cases to the level of metalaxyl treatment (Table 3).

Studies were conducted to determine storage conditions for optimum survival of AB254 on sweet corn seed. Survival of AB254 on seed was enhanced by either maintaining a low storage temperature or reducing relative humidity $(\mathrm{RH})$. Initial studies showed that viable cell counts declined from about $10^{8}$ to $10^{4} \mathrm{CFU}$ per seed over a period of 300 days at room temperature and ambient RH. When RH was maintained at $11 \%$, seed treated with $10^{8}$ CFU per seed of AB254 lost less than one $\log$ after 180 days at either 4 or $21^{\circ} \mathrm{C}$. When RH was not controlled, bacterial survival was better at $4^{\circ} \mathrm{C}$ than at $21^{\circ} \mathrm{C}$.

$P$. aureofaciens $\mathrm{AB} 254$ provided effective biological control of Pythium seed rot in sweet corn as well as in several cucurbitaceous crops. Disease control was obtained over a range of soil conditions, and low temperature or low RH during storage extended the shelf life of treated seed. However, Bozeman Biotech opted not to pursue development of AB254 as a biological control agent for seed treatment based on the high cost of the freeze-dried formulation of the organism. It would also be necessary to obtain toxicological data required by EPA for an Experimental Use Permit to test AB254 on more than 10 acres. Full registration with the EPA could not be justified without large-scale testing. "Downstream" developmental costs such as these pose serious barriers to minor-use products, of which AB254 is a prime example. As a result, the rights to develop this technology reverted back to Montana State University. No further progress has been made in the attempt to commercialize this organism.

\section{Rhizobacteria for Biocontrol of Wheat Take-all}

Efforts to develop a commercial product for biological control of wheat take-all grew out of research on the microbiological basis for the induced disease suppression responsible for take-all decline following long-term wheat monoculture (Fig. $3)$. Disease suppression in response to long-term crop monoculture is nature's counterpoint to the crop rotation effect. However, rather than the mixed array of soil- and crop-residue-inhabiting antagonists responsible through a wide variety of mechanisms for lowering the inoculum potential of pathogens between susceptible crops, the induced suppression responsible for take-all decline is due specifically to antibiotic-producing rhizobacteria sup-

\begin{tabular}{|c|c|c|c|c|c|c|}
\hline \multirow{2}{*}{$\begin{array}{l}\text { Seed } \\
\text { treatment }\end{array}$} & \multicolumn{3}{|c|}{ Pea cultivar } & \multicolumn{3}{|c|}{ Squash cultivar } \\
\hline & $\overline{\text { Super Sug. I }}$ & gar Ann & Wando & Table King & Zucchini & Crookneck \\
\hline Metalaxyl & $84 \mathrm{a}^{\mathrm{y}}$ & $94 \mathrm{a}$ & $91 \mathrm{a}$ & $74 \mathrm{a}$ & $78 \mathrm{a}$ & $58 \mathrm{a}$ \\
\hline $\mathrm{AB} 254^{\mathrm{z}}$ & $71 \mathrm{~b}$ & $91 \mathrm{a}$ & $86 \mathrm{a}$ & $76 a$ & $79 a$ & $60 \mathrm{a}$ \\
\hline Untreated & $30 \mathrm{c}$ & $69 \mathrm{~b}$ & $73 \mathrm{~b}$ & $62 \mathrm{~b}$ & $71 \mathrm{a}$ & $44 \mathrm{~b}$ \\
\hline \multicolumn{7}{|c|}{$\begin{array}{l}\text { weas planted at Western Agricultural Research Center on } 9 \text { May } 1997 \text {; squash planted on } 19 \\
\text { May } 1997 . \\
\text { x Applied at } 0.3 \mathrm{~g} \text { a.i./kg. } \\
\text { y Mean separation within columns by protected LSD }(P<0.05) \text { with } 6 \text { replicates. } \\
\text { z Coated with a suspension of AB254 in carboxymethylcellulose }(\mathrm{CMC}) \text { and } 0.25 \mathrm{M} \text { sucrose, } \\
\text { air-dried before planting. }\end{array}$} \\
\hline
\end{tabular}

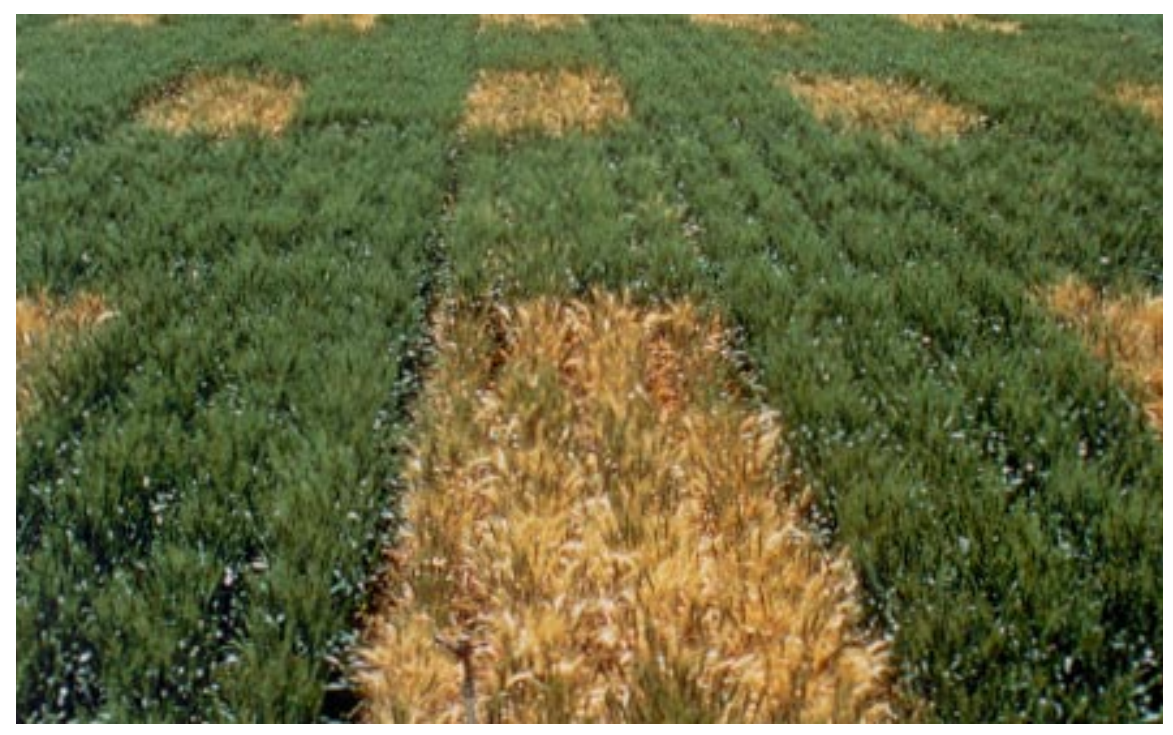

Fig. 3. Demonstration of effectiveness of induced suppression to take-all following 15 years of continuous irrigated wheat on Washington State University experiment station at Lind, WA. Prior to planting to winter wheat, three $7-\mathrm{m}$-wide strips were fumigated with methyl bromide across rows, alternated with similar nonfumigated strips. Alternating four-row drill strips of wheat were planted with and without oat grain inoculum of Gaeumannomyces graminis var. tritici. Reading treatments vertically, plots with wheat dying prematurely (white heads) represent combination of fumigated soil plus introduced inoculum alternated within drill strips with natural soil (natural inoculum) plus introduced inoculum. Solid green drill strips represent fumigated soil with no introduced inoculum and natural soil with natural inoculum. Yields averaged 95,80 , and $15 \%$ of fumigated check (no or surviving inoculum only) for natural inoculum only, natural plus introduced inoculum, and fumigated soil plus introduced inoculum, respectively. After several years of severe take-all, worst in the seventh year of monoculture, yields recovered to within $95 \%$ of that attainable in fumigated plots (in the fifteenth year), and even the addition of inoculum into the seed furrow at planting caused only modest disease unless suppressiveness was eliminated by soil fumigation. 
ported by roots infected with the wheat take-all fungus, Gaeumannomyces graminis var. tritici $(16,39,40)$. Take-all decline is an example of biological control by resident, root-associated microorganisms (15). Scientifically, the research done to explain take-all decline can claim two firsts: the first to prove that ability to produce an antibiotic has ecological and survival significance to microorganisms in soil $(38,49)$, and the first to demonstrate the specific microbiological and molecular mechanisms involved in "conversion" of soil to greater productivity in response to a cropping system for reasons other than improved soil fertility $(39,40)$.

Whether or not a commercial product comes from this work, take-all decline is exploited with confidence by wheat growers in the Pacific Northwest and Great Plains states and, indeed, throughout the world. Moreover, take-all decline has been shown to develop with direct-seeding (notill) as well as with conventional seeding (39). Cook et al. (16) point out that wheat, like other annual crops, evolved by reseeding itself in the same soil without tillage over many centuries. They speculate that the induced suppression with longterm monoculture, exemplified by take-all decline, could be so effective as to eliminate selection pressure for genetic resistance and account for the lack of useful genes for resistance to root diseases compared with leaf diseases. In a real sense,

Table 4. Influence of fluorescent Pseudomonas strains on yields of Stephens winter wheat when applied on the seed sown as replicated drill strips in a conventionally tilled commercial field naturally infested with Gaeumannomyces graminis var. tritici ${ }^{\mathrm{x}}$

\begin{tabular}{lc}
\hline Seed treatment & $\begin{array}{c}\text { Yield } \\
(\mathbf{t} / \mathbf{h a})^{\mathbf{y}}\end{array}$ \\
\hline None (check) & $3.6 \mathrm{c}$ \\
Baytan + Apron + Captan & $4.6 \mathrm{a}$ \\
Baytan & $4.6 \mathrm{a}$ \\
Baytan + Strain 30-84 & $4.6 \mathrm{a}$ \\
Strains 2-79 + 13-79 + R4a-80z & $4.5 \mathrm{a}$ \\
Strain 30-84 & $4.2 \mathrm{ab}$ \\
Strain 2-79 & $3.9 \mathrm{bc}$ \\
Methyl cellulose only (check) & $3.6 \mathrm{c}$ \\
\hline
\end{tabular}

${ }^{x}$ Fungicides and the methyl cellulose used to stick the bacteria on the seed were included as checks. Strains 2-79 and 30-84 produce phenazine antibiotics. The test was done in 1984 near Mt. Vernon, WA. Data of R. J. Cook and D. M. Weller, unpublished.

y Average yields for four replicate drill strips $(2.4 \times 75 \mathrm{~m})$ planted with a commercial drill. Values with the same letter are not significantly different at $P=0.05$.

z These strains are Pseudomonas fluorescens isolated by $\mathrm{D}$. $\mathrm{H}$. Weller from the rhizosphere of wheat seedlings grown in soil from fields that had undergone take-all decline. antibiotic-producing root-associated microorganisms are part of the plant, and if these symbionts can muster an effective and dependable defense, true genetic resistance becomes redundant. The question is whether this biological control responsible for take-all decline can be augmented, "jump-started," or otherwise duplicated with either a single antagonist or a mixture of introduced antagonists. The research and development invested in this project may well represent the longest concentrated effort ever invested in biological control of a plant disease with introduced antagonists. Of the 33 years invested in research on take-all decline (1967 to present), nearly 20 of these years (since 1980) have been invested in research to develop a commercial product. Moreover, this has been a team effort involving, in addition to a long line of outstanding graduate students and postdoctoral associates, David Weller and Linda Thomshow with USDA-ARS at Pullman, working, respectively, on rhizosphere microbiology and molecular biology, and Rodney Bothast and Patricia Slininger with USDA-ARS at the Northern Regional Research Laboratory at Peoria, working on development of fermentation and related scaleup science and technology (46). Despite the magnitude of this effort, it pales by comparison with the research and development effort-public and private-expended to control a single human disease, e.g., chicken pox, malaria, diabetes, or AIDS.

The information presented here is mainly on the field testing phases. This 20year effort can be divided into three phases.

The first phase of this research focused on performance of phenazine-producing fluorescent Pseudomonas species, notably $P$. fluorescens 2-79 and $P$. aureofaciens 3084 , including tests in grower's fields with both replicated small plots $(2.4 \times 8 \mathrm{~m})$ and 0.1 -acre replicated drill strips (Table 4; Fig. 4). These strains also became the model systems for demonstration of the ecological and biocontrol significance of

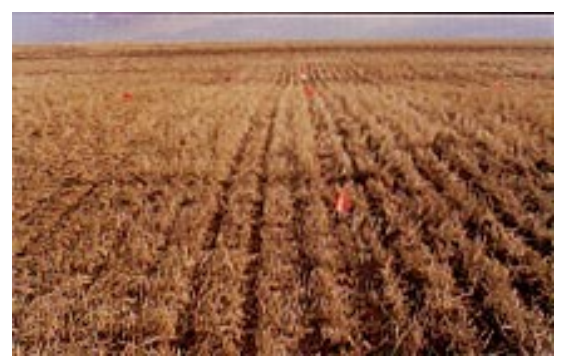

Fig. 4. Typical direct-seeded field experiment conducted with wheat after wheat in a grower's field used for testing strains of seed-applied rhizobacteria for biological control of take-all. This site was planted to spring wheat after winter wheat and received "best management" for direct-seeded wheat in the Inland Northwest. antibiotic production $(38,49)$. Based on impressive early field results of 20 to $25 \%$ increased yield of wheat in response to seed treatment with these pseudomonads (Table 5), Allied Corp. of Syracuse, New York, negotiated a patent license (54) from the USDA-ARS that was issued through the National Technical Information Service (NTIS) of the U.S. Department of Commerce in 1984. Approximately 2 years later, this license reverted to the USDA when Allied made a corporate decision to discontinue their investments in agricultural products. This led immediately to expressions of interest in this technology by two multinational agrichemical companies and one start-up biotechnology company. On 16 October 1987, NTIS published notice in the Federal Register (CR vol. 52, no. 200) of "Intent to grant Exclusive Patent License: Monsanto Co., St. Louis." However, before a license could be issued, Monsanto withdrew their request when the company decided to eliminate their inhouse effort on microbial biocontrol and focus entirely on transgenic crops. USDA field tests with these strains were discontinued when it was discovered that the phenazine mechanisms did not work in high-clay soils (35) — the age-old nemesis of antibiotics in soil. The tests also revealed another familiar problem: that control of just one disease, e.g., take-all, sometimes favored other root diseases such as Rhizoctonia and Pythium root rots. In addition, phenazine-producing strains have since been discounted for any significant role in take-all decline based on the work of Raaijmakers et al. (40); working with a probe and polymerase chain reaction (PCR)-based sequences from one of the phenazine genes as a primer, they could find no consistent presence of phenazineproducing bacteria in the rhizosphere of

Table 5. Influence of Pseudomonas fluorescens strains on yields of Madsen winter wheat when applied on seed planted directly into undisturbed soil (no-till) in a field naturally infested with Gaeumannomyces graminis var. tritici, Rhizoctonia solani AG8, and Pythium spp. ${ }^{\mathrm{y}}$

\begin{tabular}{ll}
\hline Seed treatment & $\begin{array}{l}\text { Yield }^{\mathbf{z}} \\
(\mathbf{t} / \mathbf{h a})\end{array}$ \\
\hline None (check) & $5.0 \mathrm{c}$ \\
Dividend & $6.1 \mathrm{abc}$ \\
P. fluorescens Qc69 & $6.6 \mathrm{a}$ \\
P. fluorescens $30-84$ & $5.8 \mathrm{abc}$ \\
P. fluorescens Qz29 & $5.2 \mathrm{bc}$ \\
\hline
\end{tabular}

y Test was conducted in 1993 in a commercial field near Colfax, WA. Data of R. J. Cook and D. M. Weller, unpublished.

${ }^{z}$ Average yields for six replicate plots $(2.4 \times 8 \mathrm{~m})$ planted with a plot drill. Values with the same letter are not significantly different at $P=0.05$. 
wheat growing in soil from fields that had undergone take-all decline. Nevertheless, the phenazine mechanism is of continuing interest as a means to broaden the effectiveness of biological control in the wheat rhizosphere, and basic research on this mechanism has continued, including identifying and sequencing the genes responsible for phenazine biosynthesis (48).

In the second phase of this research, several new but very important criteria were introduced into the testing program, including: (i) the strains, to be useful, had to work under no-till or direct-seed conditions (Fig. 5) because of the projection that this new method of wheat farming will become the standard in the Pacific Northwest and Great Plains states, indeed, worldwide, at least for dryland wheat; (ii) the strain(s) had to be compatible with existing chemical seed treatments used to control smuts and seed rot; and (iii) the strain(s) had to be effective against Rhizoctonia and Pythium root rot as well as take-all, or at least not result in greater damage from one or the other of these two root diseases. In tandem with this phase of the project, a major effort was launched to develop "best" agronomic practices for direct seeding wheat into wheat or barley stubble based on a belief that (i) the inoculum potential of the pathogens must be kept as low as possible to avoid the potential for "swamping" the introduced antagonist with the pathogen (4), and (ii) no seed treatment should be expected to make up for poor placement of seed or fertilizer or other inadequacies on the part of the management system. In other words, biological seed treatments as an augmentation to resident antagonists should be considered as only one component of a system aimed at achieving the high yields possible with

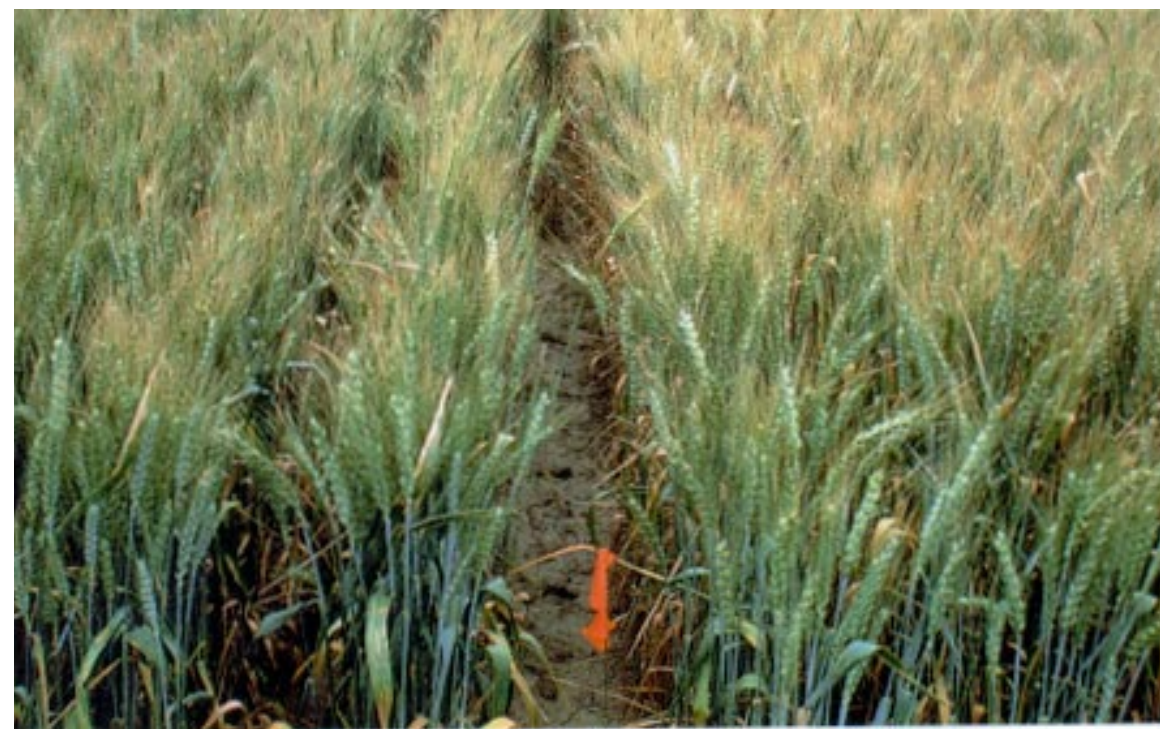

Fig. 5. Example of adjacent plots of winter wheat seeded after winter wheat with "best management" either without seed treatment (left) or with seed treated with Pseudomonas aureofaciens $\mathbf{3 0 - 8 4}$ (right). This strain and other phenazine-producing strains have since been dropped from the field-testing program because of evidence that the phenazine mechanism of biological control is not effective in high-clay soils. tion. Best management includes timely and barley plants before planting (47), use of new (current-year) seed (21), and placement of fertilizer directly beneath the seed at the time of planting to make nutrients maximally accessible even to diseased roots (10).

P. fluorescens Q69c-84 (37) and Bacillus sp. L324-92 (26) were the strains of choice during this second phase of the project. Each seemed broadly adapted based on performance in the field (Table 6). Interestingly, Q69c-84 could not be shown to produce an antibiotic and was therefore a source of curiosity as to what other mechanism(s) might be useful for biological control of take-all. In contrast, Bacillus sp. L324-92 had in vitro antibiotic activity against all isolates of $G$. graminis var. tritici, as well as all species and anastomosis groups of Rhizoctonia and all species of Pythium tested (26). This strain was also of interest because of its ability to grow over the range of 5 to $35^{\circ} \mathrm{C}$, and because it had modest ability as a rhizosphere colonist (27). L324-92 was not thought to play a role in take-all decline, since the microorganisms responsible for take-all decline are sensitive to moist heat at only $55^{\circ} \mathrm{C}$ (15), but this strain was nevertheless a product of using long-term monoculture wheat to enrich for strains of antibiotic-producing bacteria adapted to the rhizosphere of wheat. A Bacillus strain was also of interest because of its ability to produce spores and, therefore, its potentially longer shelf life.

Strain L324-92 actually fits more appropriately in our first category of antagonist discussed above-useful for protection of seeds and seedlings-but is thought to direct seeding with short or no crop rotaeffective elimination of volunteer wheat or have potential for protection of roots at least $10 \mathrm{~cm}$ deep in the soil (27), which is roughly the layer occupied by wheat root pathogens under no-till conditions. Strains L324-92 and Q69c-84 both are fully compatible with the standard chemical seed treatments used on wheat in the Pacific Northwest, including both Dividend/Apron and Raxil/thiram (17). In fact, the best results with these strains have been obtained with chemical-biological combinations rather than with only chemicals or only biological seed treatments. However, the key problem now was whether the dosages required for performance in the field were low enough to attract a commercial investor. Strain Q69c-84, like 2-79 and 30-84, requires a dose of $10^{7} \mathrm{CFU}$ per seed, which is one and possibly two log units too high to be economical based on current prices for seed treatments on wheat. Strain L324-94 requires a dose of $10^{6}$ or $5 \times 10^{5} \mathrm{CFU}$ per seed for performance, which is also possibly too high to be economical. Field tests are continuing with L324-92 at $10^{4}$ and $10^{5} \mathrm{CFU}$, including 0.1 -acre replicated drill strips but still cumulatively under 10 acres (in accordance with the U.S. Federal Insecticide, Fungicide, and Rodenticide Act, which prohibits testing a microbial pesticide on more than 10 acres without an Experimental Use Permit or full registration). Interestingly, L324-92 showed a growth-promoting benefit on turfgrass when applied to the foliage as a cell suspension (inundative applications), and a license was awarded in 1998 to Green Releaf Biotech, Inc., Jacksonville, Florida, for further development and commercialization of this strain for use on turfgrass.

Table 6. Influence of Bacillus sp. L32492 on yields of Penawawa spring wheat when applied on seed planted directly (no-till) into undisturbed soil following either spring wheat or spring barley ${ }^{\mathrm{y}}$

\begin{tabular}{lc}
\hline Seed treatment & Yield $^{\mathbf{z}}(\mathbf{t} / \mathbf{h a})$ \\
\hline Spring wheat after spring & wheat \\
None (check) & $2.7 \mathrm{~b}$ \\
Fumigated soil & $3.3 \mathrm{a}$ \\
Methyl cellulose & $2.6 \mathrm{~b}$ \\
L324-92 & $3.7 \mathrm{a}$ \\
Spring wheat after spring barley \\
None & $2.5 \mathrm{~b}$ \\
Fumigated soil & $3.3 \mathrm{a}$ \\
L324-92 & $3.2 \mathrm{a}$ \\
\hline
\end{tabular}

$\mathrm{y}$ The test was conducted in a commercial field near Dusty, WA, naturally infested with Gaeumannomyces graminis var. tritici, Rhizoctonia solani AG8, and Pythium species. Test included replicate plots fumigated with methyl bromide to produce "pathogenfree" checks. Data of Kim et al. (26).

$\mathrm{z}$ Average yields for six replicate plots $(2.4 \times 8 \mathrm{~m})$ planted with a plot drill. Values with the same letter are not significantly different at $P=0.05$. 
The third and current phase of this research was launched with the discovery of the role of 2,4-diacetyl phloroglucinolproducing fluorescent Pseudomonas strains in take-all decline $(23,24)$. Following the protocols used to estimate populations of phenazine-producing strains, but using a primer developed for one of the phloroglucinol biosynthetic genes, Raaijmakers et al. (41) showed a direct and close relationship between populations of strains with ability to produce 2,4-diacetyl phloroglucinol and their ability to suppress take-all. Furthermore, Raaijmakers and Weller (39) showed that a population of $10^{5} \mathrm{CFU} / \mathrm{g}$ fresh weight of wheat root was sufficient for almost complete control of the disease. Soils collected throughout the United States, including from Plot 2 started by $\mathrm{H}$. L. Bolley in 1882 as a monoculture wheat plot at Fargo, North Dakota, all have shown populations of phloroglucinol-producing bacteria in the range of $10^{5} \mathrm{CFU} / \mathrm{g}$ of wheat root when planted to wheat in the greenhouse (B. M. Gardner, K. Schroeder, S. Kalloger, J. Raaijmakers, L. S. Thomashow, and D. M. Weller, unpublished). Remarkably, the strains represented by Q8R1-96 are genetically very similar based on DNA fingerprinting. They are also aggressive as root colonists and therefore have the potential to solve both the economic problem of high inoculum requirements for activity in the field and inconsistency in root colonization caused by effects of the soil environment or competition from resident rhizosphere colonists. One of these strains, P. fluorescens Q8R196 , is compatible with chemical seed treatments (Table 7) and can be applied at $10^{2}$ to $10^{3} \mathrm{CFU}$ and still achieve $10^{5} \mathrm{CFU}$ in the rhizosphere (Table 4) $(39,40)$. This strain and its derivatives have been licensed for commercial development on

Table 7. Influence of Pseudomonas fluorescens Q8R1 on yields of Madsen winter wheat when applied on seed planted directly (no-till) into standing stubble of spring wheat in a field naturally infested with Gaeumannomyces graminis var. tritici, Rhizoctonia solani AG8, and Pythium spp. ${ }^{\text {. }}$

\begin{tabular}{lc}
\hline Seed treatment & Yield $^{\mathbf{z}}(\mathbf{t} / \mathbf{h a})$ \\
\hline Check & $4.9 \mathrm{~b}$ \\
Q8R1 & $5.4 \mathrm{a}$ \\
Dividend + Apron & $5.3 \mathrm{a}$ \\
Dividend + Q8R1 & $5.3 \mathrm{a}$ \\
Raxil-Thiram & $4.9 \mathrm{~b}$ \\
Raxil-Thiram + Q8R1 & $5.6 \mathrm{a}$ \\
\hline y Q8R1 produces 2,4-diacetyl phloro- \\
glucinol. Test was conducted in 1997 \\
near Colfax, WA. Data of R. J. Cook \\
and D. M. Weller, unpublished. \\
x Average yields for six replicate plots \\
(2.4 $\times 8$ m) planted with a plot drill. \\
Values with the same letter are not \\
significantly different at $P=0.05$. \\
\end{tabular}

both turfgrass and cereals by EcoSoil of San Diego. In addition, the genes for production of 2,4-diacetyl phloroglucinol have been characterized and sequenced $(6,48)$.

As part of this third phase of research toward development of a commercial product, strain Q8R1-96 was transformed by Huang et al. (22) to produce phenazine1-carboxylate as well as 2,4-diacetyl phloroglucinol. Greenhouse tests showed that the $7 \mathrm{~kb}$ of DNA inserted for phenazine production added significant activity against Rhizoctonia root rot in addition to biological control of take-all, yet had no effect on its aggressive ability as a root colonist. In the first and only field test conducted in 1998, spring wheat treated with the transgenic strain had an average of $16 \%$ higher yield than the wildtype checks in a field plot at Pullman and managed to favor all three root diseases (D. M Weller, R. J. Cook, and K. Schroeder, unpublished).

\section{Phialophora sp. l-52 for Biocontrol of Wheat Take-all}

In addition to bacteria that have been implicated in take-all decline, several fungi have also been isolated from wheat roots and/or from decline soils that are inhibitory to Gaeumannomyces graminis var. tritici $(19,45)$. One of these is a Phialophora sp., isolate I-52, originating from a field in northeastern Montana where take-all had been quite serious but later declined in severity (Figs. 6 and 7). Andrade et al. $(2,3)$ originally isolated I-52 directly from soil and showed in greenhouse tests that it had the potential to be a biocontrol agent for take-all, and Zriba et al. (58) identified I-52 as belonging to the genus Phialophora. Wong et al. (56) determined that a cold-tolerant strain of a Phialophora sp. with lobed hypopodia provided enhanced control of take-all in Australia. It has been patented and is under commercial development. It is unclear whether fungi such as these fall into the first category, i.e., antagonists applied directly to the infection court, or the third category, where the

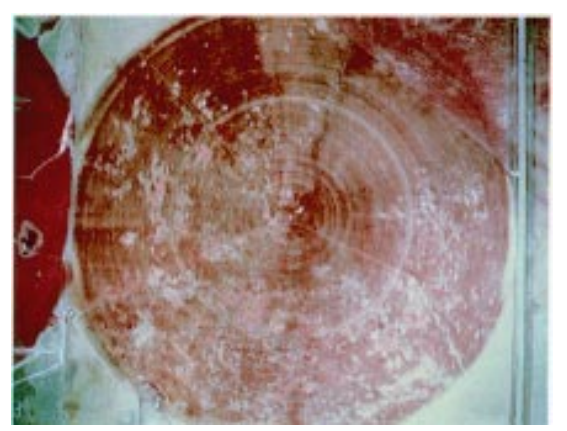

Fig. 6. Infrared aerial photo of a centerpivot irrigated spring wheat field in Montana with severe take-all infection. Healthy plants appear dark red while the light areas are plants with take-all infection. agent is released only one time and then establishes itself in the soil.

To determine whether Phialophora I-52 could function under field conditions, tests were established in which it was grown on autoclaved oat kernels, dried, and then added to the furrow at the time of seeding, along with seed and inoculum of the takeall fungus. Five years of studies showed that I-52 could provide control of take-all, with the best control occurring on winter wheat as contrasted to spring wheat (33). The level of control provided by I-52 was better if take-all severity was not extreme.

With the success of these field tests, the next step toward commercialization of such a biocontrol agent was to develop a system for producing inoculum that was more likely to succeed than use of autoclaved oat kernels as a substrate. The ideal situation would involve liquid fermentation of the biocontrol agent, followed by formulation in a dry form that would allow long shelf life and ease of application, e.g., granules that could be applied using fertilizer application equipment. Therefore, tests were carried out to determine if I-52 could be grown in a liquid formulation that would be applicable to development of dry granules. Use of potato dextrose broth in an Erlenmeyer flask on a rotary shaker resulted in mycelium that formed a tight growth around the inside of the flask. Not a good thing! However, use of King's medium B, a culture medium commonly used for growth of Pseudomonas bacteria, proved to be ideal, in that the mycelium formed as small pellets in the shake flask.

Once a good fermentation medium had been discovered, the next step was to formulate the fermented mycelium into a granular form, and for this, we opted to try using a "pesta" technique pioneered by Connick et al. (9), who developed it for formulating conidial suspensions to be used in weed biological control tests. This was successful and is carried out as follows: semolina flour and Kaolin clay (4:1 ratio) are mixed dry. Then the fermented mycelial pellets and associated growth medium are added to the flour-clay mixture in a ratio of $125 \mathrm{ml}$ of myceliumgrowth medium to $200 \mathrm{~g}$ of flour-clay mixture. This mixture is kneaded together to form a moist doughball, which is then

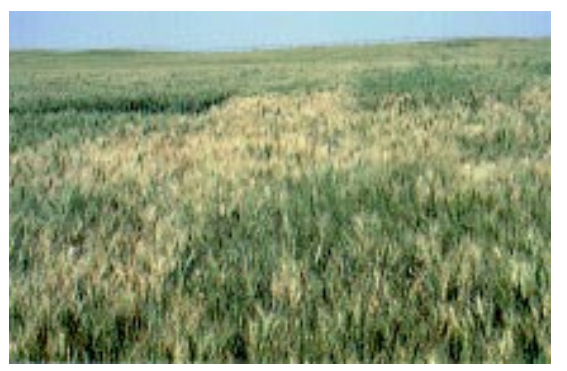

Fig. 7. White head patches in irrigated durum spring wheat typical of take-all infection. 
run through a pasta maker to form long strings of "spaghetti" (Fig. 8). These are air-dried overnight, fragmented in a Waring blender, and sieved to form granules approximately 3 to $4 \mathrm{~mm}$ long and 1 to 2 $\mathrm{mm}$ diameter. These granules can then be added to the furrow at the time of planting along with seed.

While the formulation described above appears to be effective, it is quite expensive to make. Two major expense items come from the cost of Proteose Peptone B used in Medium B, and in the Kaolin clay used in the pesta mix. Current efforts are under way to find less expensive alternatives to these ingredients. Preliminary results suggest that a yeast-molasses medium will substitute for Medium B, and that bentonite clay may substitute for Kaolin clay. Both items greatly decrease the cost of production and formulation.

\section{Overcoming the Obstacles to Commercialization}

Weller (52) has reviewed the more important reasons for failure or inconsistent performance of biological control in the rhizosphere with introduced microorganisms, including the following: disease pressure is too low for an effective test; the treatment favors increased damage from a nontarget disease; root colonization by the introduced strain is variable, or the strain has lost ecological competence; and antibiotic production, where necessary for biological control, is expressed too late or in quantities too limited for effective biologi- cal control. He points out, however, that these limitations can be solved through strain selection and strain improvement. Research teams may become disillusioned too early, or funding may be too short-term to continue the work until such problems are solved, but they can be solved. Consider, by comparison, the years and team effort required to produce a new vaccine or new cultivar of a crop plant.

Other challenges include a mixture of institutional problems, technical limitations, and unrealistic expectations, but these problems also can and must be solved if, as a discipline, we are serious about the development of commercial products for biological control of plant diseases.

Small market potential because of specificity. Economics is both the key and a major barrier to the commercial development of microbial biocontrol agents for use in agriculture. The problem is manifested primarily by the fact that the developmental and registration costs typically must be paid by a very limited market, often the market represented by a single disease on a single crop. The regulatory burden alone, especially the cost of providing toxicological data for registration of microbial biocontrol agents with the EPA, greatly reduces the prospect for commercialization of microbial biocontrol agents for use on many minor crops (12). This situation exists despite efforts by the EPA to reduce requirements for data and streamline the regulatory process specifi- cally for "microbial pesticides." The USDA-Land Grant University Interregional Project 4 (IR-4) is possibly the best route to registration of these agents for use on minor crops.

The economic and other problems raised because of the minor-use issues reflect a more fundamental institutional problem in the United States, and in many if not most other countries, which is an absence of an infrastructure for scaleup and commercialization of microbial biocontrol agents (11). A system is needed equivalent to the system developed for release and scaleup of new cultivars of crops developed by private and public plant breeders. The system needs to take safety and efficacy into account but should not be based on the pesticide model as it is now. Only with significant changes in mechanisms for approval and scaleup can we expect to make use of agents uniquely effective against one disease on one crop or potentially useful on a crop of very limited acreage such as sweet corn.

Finding the right strain. It is relatively easy to find antagonists of plant pathogens for study under laboratory and greenhouse conditions. It can be quite another matter to find an antagonist that will work consistently and effectively in the field. This may involve luck or years of screening and testing. The commercial scaleup of penicillin production during World War II followed the discovery of the "bonanza strain" of Penicillium, namely $P$. chrysogenun NRRL 1951 isolated from a
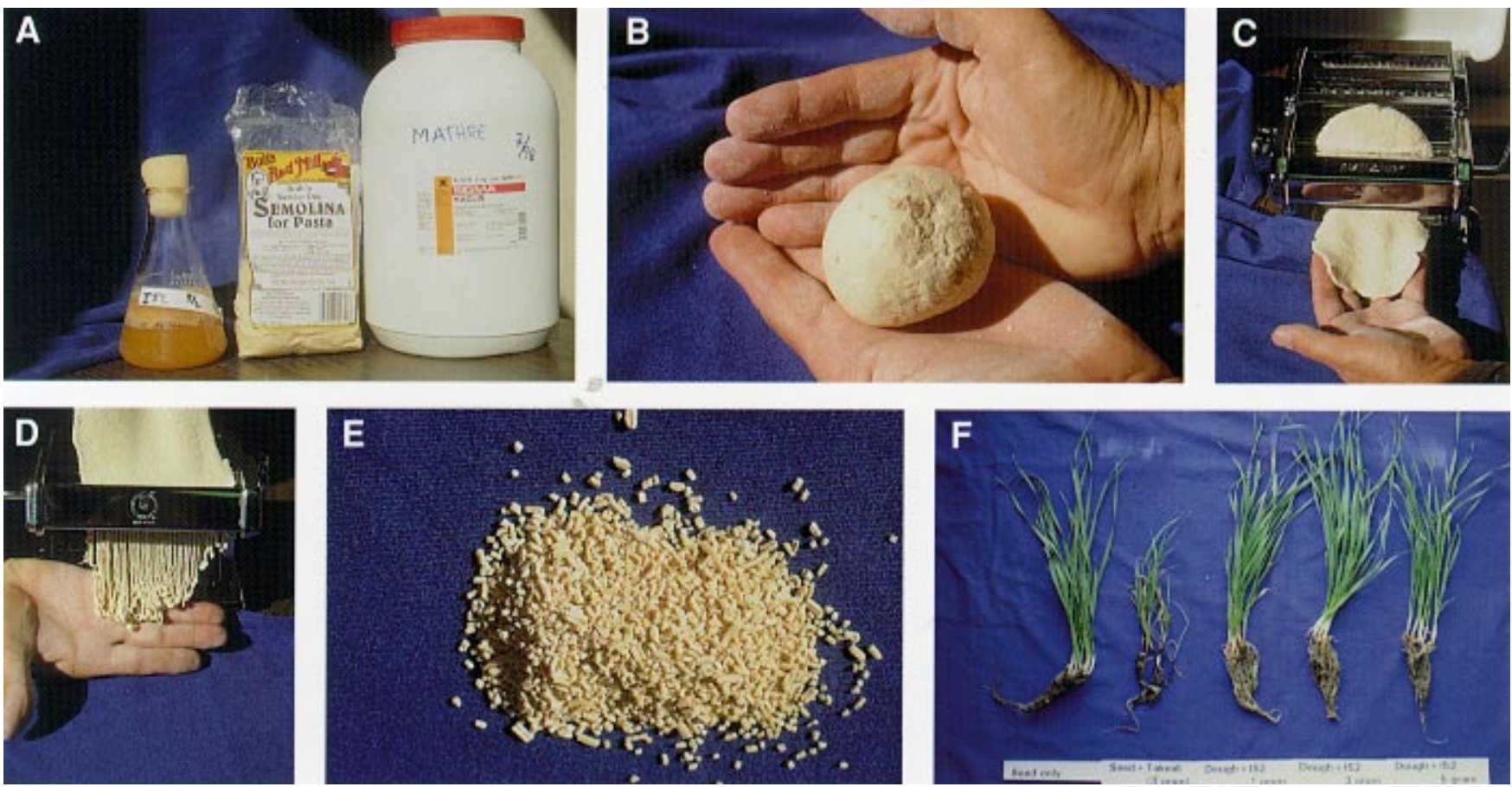

Fig. 8. Steps in the production of pesta granules containing inoculum of Phialophora sp. I-52: (A) three ingredients-shake culture of I-52, semolina flour, and kaolin clay; (B) formation of a dough ball; (C) making a thin layer of dough; (D) making "spaghetti" from the layer of dough; (E) final granule pellets after the spaghetti was dried, fragmented, and sieved to a uniform size; and (F) control of take-all of wheat using pesta granules of Phialophora sp. 1-52. Left to right: healthy plants with no take-all inoculum; plants in presence of take-all inoculum only; plants in presence of take-all inoculum plus either $1 \mathrm{~g}, 3 \mathrm{~g}$, or $5 \mathrm{~g}$ of I-52 pesta granules. 
melon brought to the Northern Regional Research Laboratory in Peoria by a local resident (42). Likewise, the widespread commercial use of $\mathrm{Bt}$ for insect control followed the discovery of a superior strain of Bacillus thuringiensis by Howard Dolmage working in Brownsville, Texas. The discovery of K84 by Alan Kerr in South Australia was the breakthrough that gave rise to the successful biological control of crown gall; apparently K84 is still the strain to beat, despite tests with many other strains of Agrobacterium radiobacter or other rhizobacteria. Kim et al. (26) screened some 2,000 strains of sporeforming aerobic bacteria, from which L324-92 was selected. The discovery of the rhizosphere-competent phloroglucinolproducing rhizobacteria came only after several years of research on phenazineproducing strains of fluorescent pseudomonads but is now the basis for the expectation that the right strains are under development for biological control of takeall.

We should also be prepared to engineer strains with the traits desired if, in screening natural populations, no strain can be found with just the right traits. Crop development would still be a primitive art were it not for plant breeding based on knowledge of Mendelian genetics, and now molecular genetics. Concerns for safety of organisms modified by the tools of recombinant DNA (rDNA) technologies (see below) should be balanced by the fact that breeding and domestication of organisms for use in agriculture has, in fact, produced plants and animals that are less rather than more able to survive on their own and more rather than less dependent on human nurturing. The demonstration by Huang et al. (22) of activity against Rhizoctonia root rot in addition to take-all by adding the ability of a phloroglucinol-producing strain to produce phenazine-1-carboxylate shows that it may be possible through transformation to produce strains with the ability to control more than one disease, possibly on more than one crop, thereby broadening the market potential needed to justify the costs of development and registration. This will also require a reduction in the regulatory burden currently imposed on rDNAmodified microorganisms for use in biological control.

Finally, researchers should be prepared to conduct extensive performance trials with candidate strains before accepting one for advancement toward commercial development. Each new cultivar of wheat is typically tested for its performance over as many as 100 site years (number of sites $\times$ number of years) to produce enough data before releasing it for seed increase and commercial use. Such field testing takes years. The private partners who agree to consider the product for commercialization typically conduct their own extensive field tests, but usually not without evidence at the outset that the product has potential for commercial use.

Shelf life, storage, and application technology. The marketplace usually demands that a product have a shelf life sufficient to carry it through at least one growing season, and preferably well into the next season. Therefore, an 18-month shelf life is preferable for a commercial microbial product, with a requirement of storage at room temperature also preferred. Bacillus may be the only genus of bacteria that meets this shelf life standard, at least based on current technology available in the public domain. Most information on formulation of microbial products is proprietary. Much more basic research on formulation is needed in the public domain for all categories of antagonists, but especially gram-negative bacteria if introduced antagonists are to be used to their full potential in agriculture.

The shelf life and formulation requirements can also depend on application technology. In general, most biocontrol agents will be applied with the same equipment currently used to apply other seed treatment products, foliar sprays, or granular materials. New application strategies add to an already complex situation created by the fact that the microbial product is a living product. Moreover, a new application method will not likely be acceptable unless it is cheaper, and/or will fit into the current production scheme. So-called "hopper box" treatment of seed, whereby seed is treated as part of the operations of filling the drill or planting the seed, could replace the current practice of treatment at the seed warehouse; by treating only that seed actually planted, there is no unused treated seed. However, such a change would also eliminate one of the main advantages of biological seed treatments over chemical seed treatments since disposal of chemically treated seed is often difficult. It cannot be fed to animals or disposed of in landfill sites, whereas seed treated with biological agents probably could be easily disposed of in these ways.

In addition to compatibility with existing seed, soil, or foliar application technology, progress toward commercialization of antagonists can depend more fundamentally on whether the strain can be integrated into the cropping system. Progress on microbial biocontrol of take-all with introduced rhizobacteria was greater once it was accepted that the treatment was not a "silver bullet" and depended instead on help from the management system as a whole, including management of soil fertility, crop residue, Rhizoctonia and Pythium root rots, and take-all.

Scaleup problems and maintaining quality control. Most researchers deal in fairly small-scale situations, i.e., the growth of a bacterium in a $250-\mathrm{ml}$ Erlenmeyer flask. The conditions necessary for production of 10,000 liters of cells often differ with the type of fermentor used. Also, the growth of fungi on dry substrates often occurs in glass canning jars in the laboratory where several hundred grams of infested material can be produced. It is one thing to produce this quantity of material; it's quite another to scale this up to several tons of inoculum. This is outside the capability of most researchers. This fact reinforces the importance of teamwork, where public-sector researchers collaborate with industry scientists who have the capability of working in large production facilities. Schisler and Slininger (44) take this need one step further by screening for antagonists that can be readily grown in industrial-size fermentors.

One of the greatest challenges during scaleup is maintaining quality control. Scaleup typically involves growing the microorganisms in increasingly larger quantities, either in liquid or solid fermentation, starting with a pure culture taken from storage and ending with the biomass ready for formulation. Contamination or mutations can occur at any one of these steps, with the result that the organism applied in large-scale field trials or commercially is not the same organism used during the research phase of the project in the laboratory or at small scale. Virtually every research team that has attempted to go forward with large-scale trials or commercial development has a story to tell about the importance of quality control.

\section{Biosafety}

Cook et al. (14) identified four potential adverse nontarget effects of microorganisms used as introduced agents for biological control of pests and disease. These are competitive displacement of a beneficial microorganism, allergenicity, toxigenicity, and pathogenicity. These are the potential nontarget effects regardless of whether the strain is native, exotic, naturally occurring, or genetically engineered. They concluded further that horizontal gene transfer of a trait for biological control would become a safety concern only if the transferred trait resulted in another microorganism acquiring the potential to produce one or more of these four adverse, nontarget effects. Of the four potential nontarget effects, all but allergenicity are also desired target effects, depending on the mechanism of biological control. Since the potential nontarget effects were identified for all categories of microbial biocontrol agents, insect and weed pathogens included, it is important to examine the potential for these effects specifically for antagonists of plant pathogens.

Competitive displacement could become an issue for an antagonist introduced into the rhizosphere if, in addition to displacement of a pathogen, rhizobia or mycorrhizal fungi critical to the health of that crop were also displaced. Presumably, this kind of nontarget effect would show up in per- 
formance tests in the field as a negative rather than a positive response of the treated crop. More specific tests could be conducted, such as those of Paulitz and Linderman (36), who showed no detrimental effect of pseudomonads on mycorrhizal fungi. As one measure of the potential for nontarget displacement, it would be of interest to estimate the extent of targeted displacement, e.g., whether the use of Phlebia gigantea has lowered the population of Heterobasidion annosum in the forest ecosystem, or whether the use of Agrobacterium radiobacter $\mathrm{K} 84$ has lowered the population of $A$. tumefaciens in orchard soils.

The spores of some fungi used as antagonists could potentially be problematic as sources of allergens. Allergenicity was identified as a worker-safety issue but not as a public-health issue (14). This issue can be managed by exercising care in the workplace, such as by having workers wear dust masks.

Toxigenicity to nontarget organisms is an obvious concern where the mechanism of protection by the antagonist involves use of a secondary metabolite to inhibit a target pathogen. However, this issue need not be of concern for worker safety unless the toxicant produced by the antagonist is a component of the product handled and applied to the plant or soil. In the majority of cases, the metabolite of interest is produced after the antagonist has made sufficient growth in the habitat where it was introduced or into which it has spread. Possibly the greatest hazard with secondary metabolites is their potential for phytotoxicity to the host. This has been a problem with phenazine-producing strains of fluorescent pseudomonads applied to the seeds of wheat (R. J. Cook, personal $o b$ servation). This would be an agronomic but not an environmental or human health problem.

Pathogenicity to nontarget organisms is an obvious concern for insect and weed pathogens used for biological controlconcern that the pathogens might spread to native or beneficial insects or plants. For antagonists, the concern would be for microorganisms with potential as opportunistic pathogens of humans, such as Aspergillus ochraceus and the clinical strains of Burkholderia cepacia. These kinds of antagonists should be eliminated early in the screening process.

It is important, when considering potential adverse nontarget effects of antagonists, to also consider the effects of not using the antagonist, including nontarget effects of not controlling the disease. What are the effects of unmanaged root rot on Rhizobium nodulation or mycorrhizal fungi? What are the effects of rotating crops or tilling the soil on beneficial microorganisms or insects, birds, or other wildlife? Every option, including doing nothing, has environmental consequences.
Nevertheless, every effort should be made to assure that our commercial products for biological control of plant diseases consist of the safest as well as the most effective antagonists.

\section{Antagonist Genes for Developing Disease Resistance}

Some of the potential uses of antagonists for biological control of plant pathogens will be made obsolete by the less variable and potentially more effective delivery of biocontrol traits by transgenic plants. Nearly all private investments in biological control today, at least in the United States, are for transformation of plants to express genes from microorganisms. In these examples, the plant rather than the microorganism becomes the biological control agent. Best known, of course, is the use of the endotoxin genes from $\mathrm{Bt}$ to develop varieties of potatoes with resistance to Colorado potato beetle, cotton with resistance to boll weevil, and hybrid corn with resistance to European corn borer. Next in importance are the varieties of squash, potatoes, and papaya transformed to express coat-protein-mediated resistance to specific viruses. Several investigators have tested the potential for use of chitinase genes as a source of resistance in plants for fungal pathogens with chitin in their cell walls. Of this work, the demonstration by Matteo et al. (34) of resistance in tobacco to Alternaria alternata and Botrytis cinerea and in potato to Alternaria solani and Rhizoctonia solani transformed to express the endochitinase gene from Trichoderma harzianum looks especially promising. The technology is also available for transfer and expression of multiple genes, including entire biosynthetic pathways between organisms. Thus, the prospects exist now for development of varieties with roots that produce the antibiotics currently produced by their symbionts. Plants already produce antibiotics-phytoalexins - as a means of defense against pathogens. In fact, one of the enzymes in the biosynthetic pathway used by fluorescent pseudomonads to produce 2,4-diacetyl phloroglucinol-chalcone synthase-is the same enzyme in the biosynthetic pathway of phytoalexins in plants (6). In other words, the search for antagonists and the unraveling of mechanisms of biological control by microorganisms is perhaps more appropriately called bioprospecting for genes to develop resistant varieties.

While the possibilities for genetic transformation of plants with transgenes from antagonists are exciting, two limitations to this approach must be kept in mind. First, transformation involves a single traiteven if multigenic, it will be a single trait-whereas effective antagonists rarely if ever provide biological control by a single mechanism. Antibiotic-negative mutants of fluorescent Pseudomonas strains effective against take-all of wheat still exhibit some level of biocontrol activity (49), and Q69c-84 has activity against take-all that cannot be ascribed to an antibiotic (37). Competition in the rhizosphere and induced resistance also play important roles in the effects of plant growth promoting rhizobacteria $(51,57)$, and may well play roles in take-all decline. Multiple mechanisms lessen the chances that the pathogen will develop resistance to the antagonist. Second, the ideal plant transformant, especially if transformed to express a phytoalexin-type substance, should include the means to limit expression of the trait to specific tissues, e.g., roots, and then only in response to a challenge infection by the target pathogen. Achieving all this adds enormously to the task of molecular plant breeding. Furthermore, for crops such as wheat that involve hundreds of cultivars to produce the different market classes in the different environments, and where cultivars are commonly changed every 5 to 10 years because of the evolving races of rust fungi, it makes more sense to deliver the protection by treating the seeds with a microbial product and periodically updating the strain by artificial selection or transformation.

\section{Acknowledgments}

The help of Shelly Waters, Nina Zidack, and Jim Miller with a portion of this work is gratefully acknowledged. Financial support came in part from the Montana Agricultural Experiment Station, the USDA-SBIR program, and Bozeman Biotech, Inc.

\section{Literature Cited}

1. Adams, P. B., and Ayers, W. A. 1982. Biological control of Sclerotinia lettuce drop in the field by Sporidesmium sclerotivorum. Phytopathology 72:485-488.

2. Andrade, O. A., Mathre, D. E., and Sands, D. C. 1994. Suppression of Gaeumannomyces graminis var. tritici in Montana soils and its transferability between soils. Soil Biol. Biochem. 26:397-402.

3. Andrade, O. A., Mathre, D. E., and Sands, D. C. 1994. Natural suppression of take-all disease of wheat in Montana soils. Plant Soil 164:9-18.

4. Baker, K. F., and Cook, R. J. 1974. Biological Control of Plant Pathogens W. H. Freeman and Co., San Francisco. (Reprinted in 1982, American Phytopathological Society, St. Paul, MN.)

5. Baker, K. F., and Snyder, W. C. 1965. Ecology of soil-borne plant pathogens, prelude to biological control. University of California, Berkeley.

6. Bangera, M. G., Weller, D. M., and Thomashow, L. S. 1996. Genetic analysis of the 2,4-diactylphloroglucinol biosynthetic locus from Pseudomonas fluorescens Q2-87. Pages 383-386 in: Advances in Molecular Genetics of Plant-Microbe Interactions. Vol 3. M. J. Daniels, J. A. Downie, and A. E. Osbourne, eds. Kluewer Academic Publishers, Dordrecht, Netherlands.

7. Callan, N. W., Mathre, D. E., and Miller, J. B. 1990. Bio-priming seed treatment for biological control of Pythium ultimum preemergence damping-off in sh2 sweet corn. Plant Dis. 74:368-372.

8. Callan, N. W., Mathre, D. E., Miller, J. B., and Vavrina, C. S. 1997. Biological seed treatments: Factors involved in efficacy. Hort- 
Science 32:179-183.

9. Connick, W. J., Jr., Boyette, C. D., and McAlpine, J. R. 1991. Formulation of mycoherbicides using a Pasta-like process. Biol. Control 1:281-287.

10. Cook, R. J. 1992. A customized approach to biological control of wheat root diseases. Pages 211-222 in: Biological Control of Plant Diseases. E. S. Tjamos, G. Papavizas, and R. J. Cook, eds. Plenum Press, New York.

11. Cook, R. J. 1993. Making greater use of introduced microorganisms for biological control of plant pathogens. Annu. Rev. Phytopathol. 31:53-80.

12. Cook, R. J. 1996. Assuring the safe use of microbial biocontrol agents: A need for policy based on real rather than perceived risks. Can. J. Plant Pathol. 18:439-445.

13. Cook, R. J., and Baker, K. F. 1983. The Nature and Practice of Biological Control of Plant Pathogens. American Phytopathological Society, St. Paul, MN.

14. Cook, R. J., Bruckart, W. L., and Coulson, J. R. 1996. Safety of microorganisms intended for pest and plant disease control: Framework for scientific evaluation. Biol. Control 7:333351.

15. Cook, R. J., and Rovira, A. D. 1976. The role of bacteria in the biological control of Gaeu- mannomyces graminis by suppressive soils. Soil Biol. Biochem. 8:269-273.

16. Cook, R. J., Thomashow, L. S., Weller, D. M., Fujimoto, D. K., Mazzola, M., Bangera, G., and Kim, D.-S. 1995. Molecular mechanisms of defense by rhizobacteria against root disease. Proc. Natl. Acad. Sci. 92:4197-4201.

17. Cook, R. J., Weller, D. M., Kim, D.-S., and Thomashow, L. S. 1997. Methods and Compositions for the Simultaneous Control of the Root Diseases caused by Gaeumannomyces Graminis, Rhizoctonia, and Pythium. Patent application filed 24 January 1997.

18. Cotty, P. J., and Bayman, P. 1993. Competitive exclusion of a toxigenic strain of Aspergillus flavus by an atoxigenic strain. Phytopathology 83:1283-1287.

19. Deacon, J. W. 1973. Phialophora radicicola and Gaeumannomyces graminis on roots of grasses and cereals. Trans. Br. Mycol. Soc. 61:471-485.

20. Harman, G. E., and Bjorkman, T. 1998. Potential and existing uses of Trichoderma and Gliocladium for plant disease control and growth enhancement. Pages 229-265 in: Trichoderma \& Gliocladium. Vol. 2, Enzymes, Biological Control and Commercial Applications. G. E. Harmon and C. P. Kubicek, eds. Taylor and Francis, London.
21. Hering, T. F., Cook, R. J., and Tang, W.-h. 1987. Infection of wheat embryos by Pythium species during seed germination and the influence of seed age and soil matric potential Phytopathology 77:1104-1108.

22. Huang, Z., Thomashow, L. S., Mavrodi, D. V., Raaijmakers, J. M., Weller, D. M., and Cook, R. J. 1997. Transgenic strains for biocontrol of plant root diseases. Patent application filed 12 December 1997.

23. Keel, C., Schnider, U., Maurhofer, M., Voisard, C., Laville, J., Burger, U., Wirthner, P., Hass, D., and Defago, G. 1992. Suppression of root diseases by Pseudomonas fluorescens CHAO: Importance of the bacterial secondary metabolite 2,4-diacetylphloroglucinol. Mol. Plant-Microbe Interact. 5:4-13.

24. Keel, C., Weller, D. M., Natsch, A., Defago, G., Cook, R. J., and Thomashow, L. S. 1996 Conservation of the 2,4-diacetylphloroglucinol biosynthesis locus among fluorescent Pseudomonas strains from diverse geographic locations. Appl. Environ. Microbiol. 62:552563.

25. Kerr, A. 1980. Biological control of crown gall through production of agrocin 84. Plant Dis. 64:25-30.

26. Kim, D.-S., Cook, R. J., and Weller, D. M 1997. Bacillus sp. L324-92 for biological

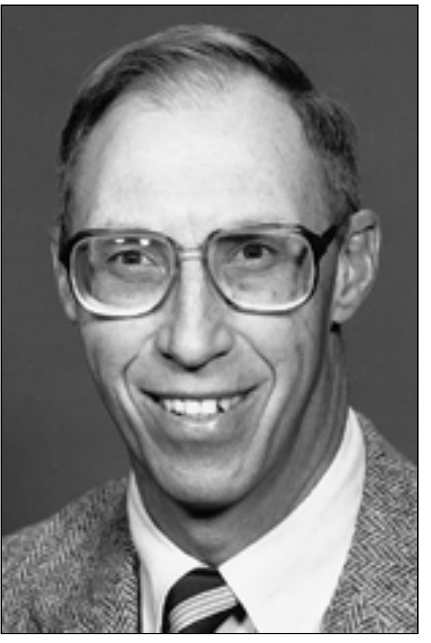

D. E. Mathre

Dr. Mathre is professor emeritus in the Department of Plant Sciences at Montana State University, Bozeman. After earning his Ph.D. at the University of California, Davis, he served on the faculty at UC-Davis for 3 years. He has been at Montana State University since 1967 . He served as head of the Department of Plant Pathology from 1987 to 1998. His research interests have been on small grain cereal diseases and on biocontrol of soilborne plant pathogenic fungi. He retired in 1998 but is still involved in research on biocontrol of soilborne pathogens.

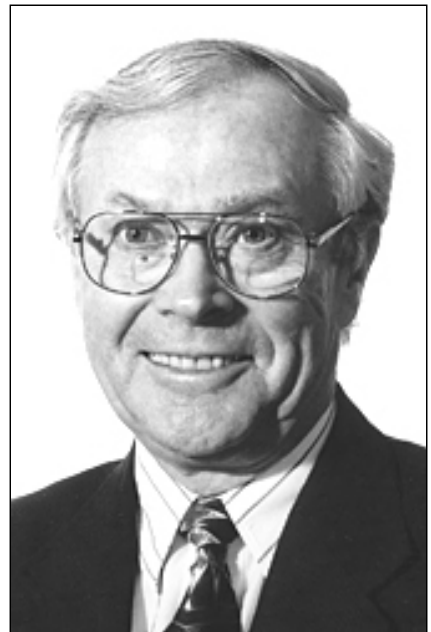

\section{R. J. Cook}

Dr. Cook was research plant pathologist and research leader with the Root Disease and Biological Control Research Unit, U.S. Department of Agriculture, Agricultural Research Service, Washington State University, Pullman. He retired from ARS in 1998 to assume a new position as the R. James Cook Endowed Chair in Wheat Research in the Departments of Plant Pathology and Crop and Soil Sciences, Washington State University. At ARS, he conducted research on root diseases of wheat and barley. Now he is part of an ARSWSU team effort to develop the knowledge and technology needed to help the Inland Northwest wheat industry increase diversity and intensity of dryland cropping while reducing dependency on tillage. He obtained his B.S. and M.S. degrees from North Dakota State University and his Ph.D. from the University of California, Berkeley. He worked in Australia at the Waite Agricultural Research Institute, University of Adelaide, as a NATO fellow in 196465 and at the Commonwealth Scientific and Industrial Research Organization, Division of Soils, Adelaide, 1973-74.

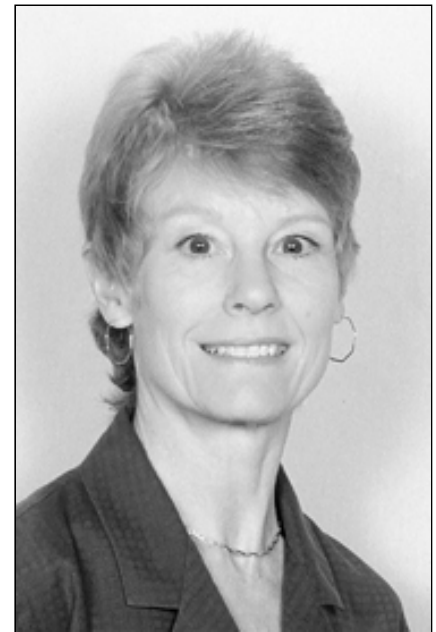

\section{N. W. Callan}

Dr. Callan is professor of horticulture in the Agricultural Experiment Station at Montana State University, Bozeman. She has been at the Western Agricultural Research Center in Corvallis, Montana, since 1980. She received B.S. and M.S. degrees from Southern Oregon University and a Ph.D. in horticulture from Oregon State University. Her research interests include the biological control of soilborne plant pathogens affecting vegetable crops, particularly Pythium ultimum, and the culture of specialty, medicinal, culinary, and essential oil crops 
control of three root diseases of wheat grown with reduced tillage. Phytopathology 87:551558.

27. Kim, D.-S., Weller, D. M., and Cook, R. J. 1997. Population dynamics of Bacillus sp. L324-92 $\mathrm{R}_{12}$ and Pseudomonas fluorescens 2$79 \mathrm{RN}_{10}$ in the rhizosphere of wheat. Phytopathology 87:559-564.

28. Kloepper, J. W., Schroth, M. N., and Miller, T. D. 1980. Effects of rhizosphere colonization by plant growth-promoting rhizobacteria on potato plant development and yield. Phytopathology 70:1078-1082.

29. Lindow, S. E. 1983. The role of bacterial ice nucleation in frost injury to plants. Annu. Rev. Phytopathol. 21:363-384.

30. Lumsden, R. D., and Walter, J. F. 1995. Development of the biocontrol fungus Gliocladium virens: Risk assessment and approval for horticultural use. Pages 263-269 in: Biological Control: Benefits and Risks. M. T. Hokkanen and J. M. Lynch, eds. Cambridge University, Cambridge, UK.

31. Mathre, D. E., Callan, N. W., Johnston, R. H., and Schwend, A. 1994. Factors influencing the control of Pythium ultimum-induced seed decay by seed treatment with Pseudomonas aureofaciens AB254. Crop Prot. 13:301-307.

32. Mathre, D. E., Johnston, R. H., Callan, N. W., Mohan, S. K., Martin, J. M., and Miller, J. B. 1995. Combined biological and chemical seed treatments for control of two seedling diseases of $\operatorname{sh} 2$ sweet corn. Plant Dis. 79:11451148.

33. Mathre, D. E., Johnston, R. H., and Grey, W. E. 1998. Biological control of take-all disease of wheat caused by Gaeumannomyces graminis var. tritici under field conditions using a Phialophora sp. Biocontrol Sci. Tech. 8:449-457.

34. Matteo, L., Woo, S. L., Fernandez, I. G., Colucci, G., Harman, G. E., Pintor-Toro, J. A., Filippone, E., Muccifora, S., Lawrence, C. B., Zoina, A., Sadik, T., and Scala, F. 1998. Genes from mycoparasitic fungi as a source for improving plant resistance to fungal pathogens. Proc. Nat. Acad. Sci. 95:7860-7865.

35. Ownley, B. H., Weller, D. M., and Thomashow, L. S. 1992. Influence of in situ and in vitro $\mathrm{pH}$ on suppression of Gaeumannomyces graminis var. tritici by Pseudomonas fluorescens 2-79. Phytopathology 82:178-184.

36. Paulitz, T. C., and Linderman, R. G. 1989.
Interactions between pseudomonads and VA mycorrhizal fungi. New Phytol. 103:37-45.

37. Pierson, E. A., and Weller, D. M. 1994. Use of mixtures of fluorescent pseudomonads to suppress take-all and improve the growth of wheat. Phytopathology 84:940-947.

38. Pierson, L. S., III, and Thomashow, L. S. 1992. Cloning and heterologous expression of the phenazine biosynthetic locus from $\mathrm{Pseu}$ domonas aureofaciens 30-84. Mol. Plant-Microbe Interact. 5:330-339.

39. Raaijmakers, J. M., and Weller, D. M. 1998. Natural plant protection by 2,4-diacetylphloroglucinol-producing Pseudomonas spp. in take-all decline soils. Mol. Plant-Microbe Interact. 11:144-152.

40. Raaijmakers, J. M., Weller, D. M., and Thomashow, L. S. 1997. Frequency of antibiotic producing Pseudomonas spp. in natural environments. Appl. Environ. Microbiol. 63:881887.

41. Raaijmakers, J. M., Weller, D. M., Thomashow, L. S., and Cook, R. J. 1997. Biocontrol Agents for Take-all. Patent application filed 24 November 1997.

42. Raper, K. B. 1978. The penicillin saga. ASA News 12:645-653.

43. Rishbeth, J. 1963. Stump protection against Fomes annosus III. Inoculation with Pleniophora gigantea. Ann. Appl. Biol. 52:63-77.

44. Schisler, D. A and Slininger, P. J. 1997. Microbial selection strategies that enhance the likelihood of developing commercial biological control products. J. Indust. Microbiol. Biotechnol. 19:192-179.

45. Sivasithamparam, K. 1975. Phialophora and Phialophora-like fungi occurring in the root region of wheat. Aust. J. Bot. 23:193-212.

46. Slininger, P. J., Van Cauwenberger, J. E., Bothast, R. J., Weller, D. M., Thomashow, L. S., and Cook, R. J. 1996. Effect of growth culture physiological state, metabolites, and formulation on the viability, phytotoxicity, and efficacy of the take-all biocontrol agent Pseudomonas fluorescens 2-79 stored encapsulated on wheat seeds. Appl. Microbiol. Biotechnol. 45:391-398.

47. Smiley, R. W., Ogg, A. G., Jr., and Cook, R. J. 1992. Influence of glyphosate on severity of Rhizoctonia root rot and growth and yield of barley. Plant Dis. 76:937-942.

48. Thomashow, L. S., and Mavrodi, D. V. 1997. The genetics and regulation of antibiotic pro- duction by PGPR. Pages 108-115 in: Plant Growth-Promoting Rhizobacteria - Present Status and Future Prospects. Japan-OECD Paris workshop. A. Ogoshi, K. Kobayashi, Y. Homma, F. Kodama, N. Kondo, and S. Akino, eds. Hokkaido University, Sapporo, Japan.

49. Thomashow, L. S., and Weller, D. M. 1988. Role of a phenazine antibiotic from Pseudomonas fluorescens in biological control of Gaeumannomyces graminis var. tritici. J. Bacteriol. 170:3499-3508

50. Tribe, H. T. 1957. On the parasitism of Sclerotinia trifoliorum by Coniothyrium minitans. Trans. Br. Mycol. Soc. 40:489-499.

51. van Peer, R., Niemann, G. J., and Schippers, B. 1991. Induced resistance and phytoalexin accumulation in biological control of Fusarium wilt of carnation by Pseudomonas sp. strain WCS417r. Phytopathology 81:728 734.

52. Weller, D. M. 1988. Biological control of soilborne plant pathogens in the rhizosphere with bacteria. Annu. Rev. Phytopathol. 26:379-407.

53. Weller, D. M., and Cook, R. J. 1983. Suppression of take-all of wheat by seed treatments with fluorescent pseudomonads. Phytopathology 73:463-469.

54. Weller, D. M., Cook, R. J., and Wilkinson, H. T. 1984. Method for screening bacteria and application thereof for field control of diseases caused by Gaeumannomyces graminis. U.S. patent 4,456,684.

55. Wells, H. D., Bell, D. K., and Jaworski, C. A 1972. Efficacy of Trichoderma harzianum as a biocontrol for Sclerotium rolfsii. Phytopathology 62:442-447.

56. Wong, P. T. W., Mead, J. A., and Holley, M. P. 1996. Enhanced field control of wheat take-all using cold tolerant isolates of Gaeumannomyces graminis var. graminis and Phialophora $s p$. (lobed hyphopodia). Plant Pathol. 45:285293.

57. Zhou, T., and Paulitz, T. C. 1994. Induced resistance in the biocontrol of Pythium aphanidermatum by Pseudomonas spp. on cucumber. J. Phytopathol. 142:51-63.

58. Zriba, N., Sherwood, J. E., and Mathre, D. E. 1999. Characterization and effectiveness of Phialophora sp. isolated from a Montana take-all suppressive soil in controlling takeall disease of wheat. Can. J. Plant Pathol $21: 110-118$. 